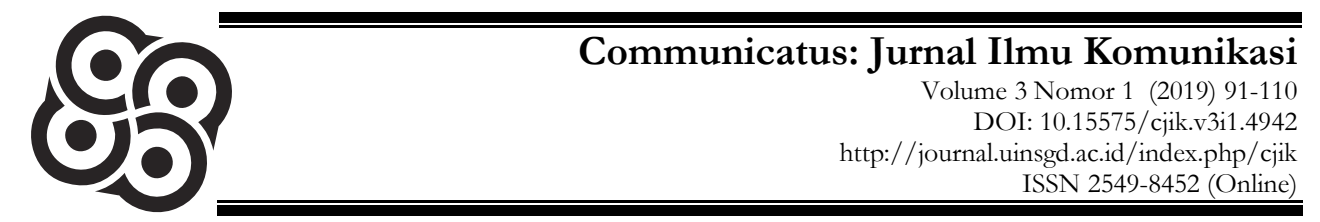

\title{
Analisis Framing Pemberitaan Pilgub Jawa Timur 2018 pada Situs Berita Daring Indonesia
}

\author{
Nur Hamidah Zulaikha \\ Universitas Dr. Soetomo Surabaya \\ zulaikba@unitomo.ac.id
}

\begin{abstract}
This study aims to analyze and determine how to frame the news media between governor candidates during the election campaign in the 2018 East Java Governor JawaPos.com, Surya.co.id \& Tempo.co using text analytics case study method through framing analysis model of Robert Entman, This study shows that every news portal provides a similar viewpoint to the East Java Governor Election 2018. The existence of viewpoints about the same or not much different will then also give a slightly different view of the news has been conveyed, moral judgment and settlement of different problems also. After indepth analysis, it turns out it is influenced by the gatekeeper. Gatekeeper customize their news with matters related to the company looks at news events of East Java Governor Election 2018 by JawaPos.com objectively, providing insight and knowledge. Meanwhile, for the message written by Surya.co.id as the latest national news portal also gives detailed information on the activities of each candidate in East Java Governor Election 2018. Unlike the news written by Tempo.co. On this news portal, East Java Governor Election 2018 which focuses on reporting the results of the debate on April 10 2018 without giving frills about the activities of each candidate Governor of East Java in 2018.
\end{abstract}

Keywords : Analysis framing, Mass media, News, Election of Governor, Gatekeeper

\begin{abstract}
ABSTRAK
Penelitian ini bertujuan untuk menganalisis serta mengetahui bagaimana media membingkai pemberitaan antar pasangan calon gubernur selama masa kampanye pemilihan Gubernur Jawa Timur 2018 di JawaPos.com, Surya.co.id \& Tempo.co dengan menggunakan metode studi kasus analisis teks melalui analisis framing model Robert Entman. Penelitian ini menunjukkan bahwa setiap portal berita memberikan sudut pandang yang hampir sama terhadap Pemilihan Gubenur Jawa Timur 2018. Adanya sudut pandang yang hampir sama atau tidak jauh berbeda tersebut selanjutnya juga memberikan pandangan yang sedikit berbeda terhadap berita yang tersampaikan, keputusan moral dan penyelesaian masalah yang berbeda pula. Setelah dilakukan analisis secara mendalam, ternyata hal tersebut dipengaruhi dengan adanya gatekeeper. Adanya gatekeeper yang menyesuaikan berita dengan hal-hal terkait perusahaan terlihat pada peristiwa pemberitaan tentang Pemilihan Gubenur Jawa Timur 2018. JawaPos.com dengan objektif, memberikan wawasan dan pengetahuan. Sementara, untuk pemberitaan yang ditulis oleh Surya.co.id sebagai portal berita nasional terkini juga
\end{abstract}


memberikan informasi detail mengenai kegiatan masing-masing kandidat pada Pemilihan Gubenur Jawa Timur 2018. Berbeda dengan berita yang ditulis oleh Tempo.co. Pada portal berita ini, Pemilihan Gubenur Jawa Timur 2018 yang berfokus pada pemberitaan hasil debat pada tanggal 10 April 2018 saja tanpa memberi embelembel tentang kegiatan masing-masing kandidat Gubenur Jawa Timur 2018.

Kata kunci: Analisis framing, Media Massa, Berita, Pemilihan Gubernur, Gatekeeper

\section{PENDAHULUAN}

Media massa mempunyai peran yang signifikan dalam menentukan arah kemajuan dan kedewasaan berpikir masyarakat, berbagai persoalan tentang ekonomi, politik, kebudayaan dan keagamaan dapat diketahui melalui media. Jika melihat sirkulasi pemberitaan yang ada di dalamnya, surat kabar adalah satu bentuk media yang sangat potensial bagi pembentukan opini public (Schramm dalam Ardhana 1995:2). Peranan media massa dalam pembangunan nasional adalah sebagai agen pembaharu, dimana media massa membantu mempercepat proses peralihan masyarakat yang tradisional menjadi masyarakat modern, khususnya peralihan dari kebiasaan-kebiasaan yang menghambat pembangunan ke arah sikap baru yang tanggap terhadap pembaharuan demi pembangunan.

Pada pasal 1 ayat 1 Undang-Undang Republik Indonesia Nomor 40 Tahun 1999 Tentang Pers disebutkan bahwa pengertian pers adalah lembaga kemasyarakatan alat perjuangan nasional yang mempunyai karya sebagai salah satu media komunikasi massa yang bersifat umum berupa penerbitan yang teratur waktu terbitnya diperlengkapi atau tidak diperlengkapi dengan alat-alat milik sendiri berupa percetakan, alat-alat foto, klise, mesin-mesin stensil atau alat-alat teknik lainnya. Sedangkan pada pasal 2 ayat 1 Undang-Undang Republik Indonesia Nomor 40 Tahun 1999 Tentang Pers pengertian pers nasional adalah alat perjuangan nasional dan merupakan media massa yang bersifat aktif, efektif, edukatif, informatoris dan mempunyai fungsi kemasyarakatan pendorong dan pemupuk daya pikiran kritis dan progresif (selalu maju) meliputi segala perwujudan kehidupan masyarakat Indonesia.

Salah satu yang menjadi topik pemberitaan pada media pers adalah peristiwa politik. Hal ini dikarenakan peristiwa politik sangat menarik untuk disimak, seperti halnya berita mengenai pemilihan Gubenur. Pada umumnya, menjelang pemilihan Gubernur, terlihat jelas usaha masing-masing kandidat untuk merebut hati masyarakat. Selain melaksanakan kegiatan kampanye langsung, masing-masing kandidat juga lihai dalam memanfaatkan peluang pencitraan di media massa. Para calon Gubernur berkepentingan untuk menciptakan citra positif, citra positif dapat ditunjukan melalui penyikapan terhadap berbagai peristiwa politik dengan membawa aspirasi politik yang sesuai dengan tuntutan publik atau konstituennya, tujuan itu kemungkinan bisa terlaksana dengan memanfaatkan saluran media massa (Muchtar, 2016: 146). 
Analisis Framing Pemberitaan Pilgub Jawa Timur 2018 pada Situs Berita Daring Indonesia

Pemberitaan pemilihan Gubernur ini merupakan agenda terpenting yang tak boleh terlewatkan untuk diberitakan oleh media. Media dan peristiwa politik merupakan satu kesatuan yang sulit untuk dipisahkan. Hubungan keduanya sangat kompleks, saling menguntungkan, serta saling melengkapi. Pelaku politik, perorangan maupun partai, media massa berfungsi untuk menyampaikan pesanpesan politik mereka kepada khalayak dengan cara yang santun. Tujuannya hanya satu yakni konstruksi opini publik yang akan sangat mempengaruhi hasil pencapaian politik. Sedangkan bagi wartawan, peristiwa politik merupakan peristiwa yang memiliki nilai berita (news values) untuk dijadikan sebagai sumber produksi pesan-pesan politik.

Sebagai sebuah peristiwa politik yang penuh dengan persaingan dan maka dalam Pilkada masing-masing calon berupaya menyusun strategi pencitraan untuk memenangkan pertarungan tersebut. Beberapa penelitian Pilkada, banyak yang mengaitkannya dengan strategi yang diterapkan diantaranya adalah Analisis dan Eksistensi Politik Kandidat Walikota dalam Meyakinkan Pemilih Pada Pilkada Kota Makassar di Tinjau dari Aspek Marketing Mix (Launtu, 2009), dan Strategi Kemenangan Pasangan Tatto Suwarto Pamuji-Akhmad Edy Susanto dalam Pilkada Kabupaten Cilacap Tahun 2012 (Insani, M. A. (2013).

Aspek fenomena dan Implementasi dalam Pilkada juga menjadi pembahasan tersendiri diantaranya tentang, Fenomena Golput Pada Pilkada Pati 2011 (Masitoh dkk, 2013), Pemantapan Wawasan Kebangsaan dalam Mengsukseskan Pilkada (Basyah, 2010), Implementasi Penerapan Pilkada pada daerah Pemekaran (Siregar, 2012), Variabel-variabel yang Mempengaruhi Rendahnnya Partisipasi Politik Masyarakat dalam Pilkada Walikota dan Wakil Walikota Padang Tahun 2008 (Hendrik, 2010), serta Kemenangan Kembali Mantan Bupati Amat Antono Pada Pilkada Kabupaten Pekalongan Tahun 2011 (Maula dkk, 2013).

Penelitian lain mengkaji tentang, Mengakhiri Sebuah Krisis Politik (Susila, 2009) dan Resolusi Konflik Pilkada di Kota Cimahi Jawa Barat (Humaedi, dkk, 2018), Local Political Dynamics In The General Election Directly Conducted To Vote For District Heads (Pilkada) In Badung Regency In 2005 (Wisnumurti, dkk, 2011), Politisasi Birokrasi dalam Pilkada Banten 2006 (Hamid, 2011) sedangkan yang terkait dengan perundang-undangan adalah penelitian tentang Peran dan Fungsi DPRD dalam Pelaksanaan Pilkada Menurut Undang-Undang No. 32 Tahun 2004 (Muis, 2009).

Bila dibandingkan dengan beberapa penelitian terdahulu, maka penelitian ini menjadi sangat berbeda, karena kajiannya lebih focus kepada kajian pilkada tenang, bagaimana media membingkai pemberitaan antar pasangan calon gubernur selama masa kampanye pemilihan Gubernur Jawa Timur 2018 .

Ada pun pemilihan Gubernur Jawa Timur 2018 diikuti oleh dua pasang kandidat, yakni pasangan nomor urut 1 Khofifah Indar Parawansa - Emil Dardak dan serta pasangan nomor urut 2 yakni Saifullah Yusuf (Gus Ipul) - Puti 
Guntur Soekarnoputri. Adapun dalam rentan waktu kampanye resmi, yakni tanggal 02 Februari 2018 - 23 Juni 2018. Pemberitaan mengenai kampanye Pemilihan Gubenur Jawa timur 2018 ini pun beragam. Beberapa media massa memberitakan persitiwa tersebut sesuai dengan gaya serta sudut pandang masing-masing.

Dimasa sekarang banyak media online berupa surat kabar yang berbasis elektronik, seperti surat kabar Jawa Pos, Detik, Tribun, Kompas, Rupublika, Tempo dan lainnya. Dalam hal ini penulis memilih JawaPos.com, Surya.co.id dan Tempo.co. Ketiga media tersebut banyak dipilih, baik oleh para kandidat ataupun pembaca karena merupakan media yang banyak digemari di Jawa Timur. Alasan lain mengapa memilih ketiga media online tersebut karena JawaPos.co.id merupakan harian terbesar di Jawa Timur, selain itu JawaPos.co.id memperoleh predikat Nenspaper of The Year oleh World Young Reader Prize di tahun 2011 dan hal ini membuat JawaPos.co.id sampai sekarang menjadi koran anak muda baik Indonesia maupun dunia (Kompas, 2015). Surya.co.id merupakan media pemberitaan uang memperoleh Gold dalam kompetisi Indonesia Print Media Award (IPMA) 2015. Sementara Tempo.co menjadi juara dunia dalam kompetisi hackathon media, yang diselenggarakan asosiasi Global Editors Network di Wina, Austria, 17 Juni 2016 (Tempo, 2016). Ketiga media pemberitaan online tersebut juga memperoleh penghargaan dari Mendikbud Muhadjir Effendy tahun 2017 kedalam 10 harian berbhasa Indonesia terbaik (BanjarmasinPost.co.id, 2017).

Pada dasarnya, dalam setiap pemberitaan, sebuah media memiliki frame tertentu. Framing berhubungan dengan proses produksi berita-kerangka kerja dan rutinitas organisasi media. Bagaimana peristiwa dibingkai, kenapa peristiwa dipahami dalam kerangka tertentu atau bingkai tertentu, tidak bingkai yang lain, bukan semata-mata disebabkan oleh struktur wartawan, melainkan juga rutinitas kerja dan institusi media secara langsung atau tidak langsung mempengaruhi pemaknaan peristiwa (Eriyanto, 2002 :115).

dibutuhkan paradigma alternatif yang lebih kritis untuk melihat relaitas lain dibalik wacana media massa. Salah satunya adalah analisis framing. Analisis framing termasuk ke dalam paradigma kontruksionis. Paradigma ini mempunyai posisi dan pandangan tersendiri terhadap media dan teks berita yang dihasilkannya. Analisis framing sendiri adalah analisis yang memusatkan perhatian pada bagaimana media mengemas dan membingkai berita. Proses itu umumnya dilakukan dengan memilih peristiwa tertentu untuk diberitakan dan menekankan aspek tertentu dari peristiwa lewat bantuan kata, aksentuasi, gambar dan perangkat lainnya (Eriyanto, $2002: 115)$.

Framing didefinisikan sebagai proses membuat suatu pesan lebih menonjol, menempatkan informasi lebih daripada yang lain sehingga khalayak lebih tertuju pada pesan tersebut. Menurut Pan dan Kosicki, ada dua konsepsi 
Analisis Framing Pemberitaan Pilgub Jawa Timur 2018 pada Situs Berita Daring Indonesia dari framing yang saling berkaitan. Pertama, dalam konsepsi psikologi. Framing dalam konsepsi ini lebih menekankan pada bagaimana seseorang memproses informasi dalam dirinya. Framing berkaitan dengan struktur dan proses kognitif, bagaimana seseorang mengolah sejumlah informasi dan ditunjukkan dalam skema terrtentu. Kedua, konsepsi sosiologis. Pandangan ini lebih melihat pada bagaimana konstruksi sosial atas realitas. Frame ini dipahami sebagai proses bagaimana seseorang mengklasifikasikan mengorganisasikan, dan menafsirkan pengalaman sosialnya untuk mengerti (Eriyanto, 2002:291)

Untuk menggabung kedua konsepsi tersebut dalam satu model, dapat dilihat dari bagaimana suatu berita di produksi dan peristiwa dikonstruksi oleh wartawan. Wartawan bukanlah agen tunggal yang menafsirkan peristiwa, sebab paling tidak ada tiga pihak yang saling berhubungan yaitu wartawan, sumber dan khalayak. Setiap pihak menafsirkan dan mengkonstruksi realitas, dengan penafsiran sendiri dan berusaha agar penafsirannya yang paling domianan dan menonjol. (Eriyanto, 2002 :291)

Wartawan media massa cenderung memilih seperangkat asumsi tertentu yang berimplikasi bagi pemilihan judul berita, struktur berita, dan keberpihakannya kepada seseorang ataupun sekelompok orang, meskipun keberpihakan tersebut sering bersifat subtil dan tidak sepenuhnya disadari. Asumsi wartawan bersifat parsial, karena tidak mewakili pihak-pihak lain: wakil rakyat, pemerintah, kaum ilmuan, LSM, kaum buruh, rakyat jelata, atau alaiansi dari dua atau tiga pihak tersebut. (Eriyanto, 2002 :291)

Dalam pendekatan konstruktivis, proses pembuatan berita sebagaimana dinyatakan Gamson dan Modilgiani dikutip dalam bukunya Eriyanto "Analisis Framing", "wacana media dapat dikonsepsikan sebagai seperangkat kemasan interpretif yang memberi makna pada suatu isu. Suatu kemasan memiliki struktur internal, Intinya adalah suatu gagasan yang mengorganisasikan, atau suatu kerangka untuk memahami peristiwa-peristiwa yang relevan, menyarankan apakah isu tersebut. (Eriyanto, $2002: 282$ )

Analisis framing cocok digunakan untuk melihat konteks sosial-budaya suatu wacana, khususnya hubungan antara berita dan ideologi, yakni proses atau mekanisme mengenai bagaimana berita membangun, mempertahankan, mereproduksi, mengubah dan meruntuhkan ideologi. Dalam penelitian tentang berita politik, analisis framing dapat digunakan untuk melihat siapa mengendalikan siapa dalam suatu struktur kekuasaan, pihak mana yang diuntungkan dan dirugikan, siapa si penindas dan tertindas, tindakan politik mana yang konstitusional dan inkunstitusional, kebijakan public mana yang harus di dukung dan tidak boleh didukung, dan sebagainya. Media massa Indonesia sangat kaya dengan wacana, yang kalau digali dengan analisis ini, akan melukiskan bagaimana perubahan kontalasi kekuasaan antara berbagai komponen atau bangsa, masyarakat, atau komunitas (Eriyanto, 2002 :15).

Berdasarkan penjelasan di atas, hubungan linear antara sistem demokrasi 
dengan kesejahteraan rakyat dalam suatu komunikasi politik khususnya pemilihan Gubernur Jatim tahun 2018 menarik perhatian media massa dan khalayak yang sangat besar. Maka mengerucutlah pokok permasalahan yang akan diteliti yaitu bagaimana media membingkai pemberitaan para pasangan calon gubenur selama masa kampanye pemilihan Gubenur Jawa Timur Tahun 2018 di JawaPos.com, Surya.co.id \& Tempo.co?

Dalam kaitannya dalam kehidupan bernegara, pers juga memiliki beberapa peran pokok yang harus diemban. Sebagai media massa dengan cakupan yang luas, sangat wajar bila hukum dan peraturan tentang pers harus diatur sedemikian rupa. Di berbagai negara, pers memiliki bentuk dan karakteristik berbeda. Dalam kajian sistem pers, Siebert membagi menjadi empat besar teori dan sistem pers, yakni authoritarian theory, libertarian theory, communist theory, serta social responsibility theory (Masduki, 2007).

Teori pers otoritarian memiliki ciri media sebagai alat propaganda pemerintah. Fungsi pers menjustifikasi kebenaran pendapat pemerintah terhadap berbagai persoalan yang muncul dalam kehidupan masyarakat. Pers boleh mengeluarkan kritik sejauh tidak bertentangan status quo rezim yang tengah berkuasa. Otoritasi perizinan media di tangan pemerintah sehingga izin dapat dicabut secara sepihak setiap saat dan sensor dilakukan secara ketat.

Teori pers komunis merupakan varian atau kelanjutan dari teori pers otoritarian. Teori ini mengatakan media bersifat integral dengan partai politik atau pemerintah tidak diperkenankan adanya kepemilikan media secara pribadi. Media menyebarkan pandangan, terutama bersumber dari ucapan pejabat Negara.

Teori pers liberal sebagai antitesis teori pers otoritarian memiliki ciri bahwa pers bukan alat pemerintah dan bisa dimiliki secara pribadi. Pers bebas dimiliki dan dioperasikan oleh siapapun, namun hukum industrial membuat kepemilikan media hanya terpusat pada pemodal besar yaitu kepentingan pemodal mengakumulasi keuntungan. Liberalisasi pers menyebabkan kontrol terhadapnya berada ditangan para pemilik modal, bukan khalayak luas.

Dalam situasi tersebut, muncul teori pers tanggung jawab sosial, yang merupakan pengembangan sekaligus kritik terhadap teori pers liberal. Pers harus dilepaskan dari intervensi pemerintah, namun sensibilias terhadap dampak buruk pers liberal yaitu kepemilikan media yang monopolistik sehingga potensi manipulasi informasi dapat diatasi dengan regulasi.

Sistem pers yang berlaku di suatu Negara tergantung pada kebijakan dan regulasi yang ada. Sedangkan kebijakan dan regulasi tersebut tidak lepas dari sistem politik pemerintahan yang ada pada Negara tersebut. Keberadaan pers dan sistem politik memiliki keterkaikan satu sama lainnya, yang menyebabkan pers tidak bisa tumbuh sendiri jika diihat dari sisi dampak ke masyarakat. Pada intinya, pertumbuhan serta perkembangan pers tidak bisa dipisahkan oleh 

adanya sistem pemerintahan yang diberlakukan di sebuah Negara (Said, 1998).

Di Indonesia sendiri, Undang-Undang Nomor 40 tahun 1999 tentang pers pada pasal 3 ayat 1 yang menjelaskan fungsi pers dan Undang-Undang Nomor 19 tahun 2016 tentang informasi dan transaksi elektronik ayat 4 tentang tanggung jawab pemberitaan oleh media, menjadi payung hukum serta rujukan regulasi bagi sistem pers yang ada. Adanya peraturan ini membuat pers Indonesia menganut kebebasan pers yang bertanggung jawab atau sistem pers tanggung jawab sosial atas pemeberitaan yang disampaikan melalui meda online. Siebert, Petersson dan Schramm dalam buku Four Theories of The Press menjelaskan sistem pers tanggung jawab sosial merupakan salah satu dari empat sistem pers yang ada di dunia (Severin and Tankadrd, 2008).

Teori tanggung jawab sosial muncul ketika adanya inisiasi dari Komisi Kebebasan Pers (Komisi Hutchin) yang mengatakan kalau media adalah industri yang dilindungi Piagam Hak Azasi Manusia yang wajib memenuhi tanggung jawab sosial kepada masyarakat. Selain memberi fungsi hiburan, sumber informasi, serta mencari keuntungan, media diminta untuk memberikan ruang bagi publik untuk menyampaikan pendapat atau masalah. Teori ini muncul diakibatkan karena adanya kesadaran bahwa penggunaan kebebasan pers telah gagal dan dinilai hanya meningkatkan kekuasaan kelas tertentu saja (Hutagalung, 2013). Adapun prinsip utama dari pers tanggung jawab sosial, yaitu: (1) Media harus menerima serta memenuhi kewajiban tertentu terhadap masyarakat, (2) Kewajiban tersebut dipenuhi dengan menetapkan standar yang profesional mengenai informasi, kebenaran, ketepatan, obyektivitas serta keseimbangan, (3) Dalam menerima serta menerapkan kewajibannya, media harus dapat mengatur diri sendiri di dalam kerangka hukum dan lembaga yang ada, (4) Media harus terhindar dari hal yang dapat menimbulkan kejahatan, kerusakan, atau ketidaktertiban umum atau penghinaan terhadap minoritas, (5) Media harus bersifat pluralis serta mencerminkan kebhinekaan masyarakat, dengan memberikan kesempatan yang sama untuk mengungkapkan berbagai sudut pandang, (5) Wartawan dan media profesional harus bertanggung jawab terhadap masyarakat.

Pada dasarnya kebebasan pers di Indonesia dengan Undang-Undang yang telah diterapkan telah memberikan landasan yang kuat bagi keberadaan industri pers itu sendiri. Jika bicara teori media normatif, pers di Indonesia merupakan gambaran dari a liberal-pluralism or marked model, dimana semakin beragamnya konten dan isu yang ditayangkan dan banyak muncul pelaku-pelaku industri media yang baru. Namun, bertambahnya jumlah media massa yang ada tidak diikuti oleh perbaikan atau peningkatan kualitas tayangan dari sisi ilmu jurnalistik. Saat ini masih terdapat konten media yang memberitakan hal-hal yang menjual informasi 'kosong'. Selain itu, konten media massa juga masih syarat akan dukungan atau penyudutan suatu pihak tertentu, dan tidak disertai pula dengan kebenaran fakta atau data yang valid (Hutagalung, 2013). 
Hal-hal tersebutlah yang memunculkan berbagai 'penyakit' sosial dimasyarakat, seperti banyaknya kasus kriminal yang diakibatkan oleh dampak dari tayangan media massa. Disinilah peran sistem pers tanggung jawab sosial, dimana diperlukan adanya tanggung jawab oleh media massa terhadap dampak konten tayangan mereka.

Analisis framing digunakan untuk menganalisa bagaimana media massa mengemas peristiwa, media massa "merekontruksi ulang" realita, peristiwa, suasana, keadaan, tentang orang, benda, bahkan pendapat-pendapat berkaitan dengan peristiwa tersebut. Redaksional media massa yakni wartawan, editor, redaktur, redaktur pelaksana, pimpinan redaksi yang mencari, meliput peristiwa, penulisan ulang, sebagai proses editing, dan menyeleksi berita-berita mana yang layak dimuat dalam surat kabar. Kriteria berita berisi $5 \mathrm{~W}+1 \mathrm{H}$ (apa, siapa, dimana, kapan, mengapa dan bagaimana), baik untuk laporan/berita langsung (hard news) maupun soft news atau feature.

Berita tidak saja berisi informasi tentang sesuatu hal, tetapi informasi tersebut harus menarik dan penting, atau memiliki nilai berita (news valeu). Siregar (1999) dalam Bharata (2004:171) mengemukakan bahwa redaksional media akan berusaha subyektifitas tentang yang apa yang menarik dan penting menurutnya akan menarik dan penting menurut pembaca (Neviati, 2018).

Entman dalam buku Bharata (2004:181) mengemukakan ide perihal framing pertama kali dilontarkan oleh Baterson pada tahun 1995. Frame pada awalnya dimaknai sebagai struktur konseptual yang mengorganisasi pandangan politik, kebijakan, dan wacana, serta menyediakan kategori-kategori standard untuk mengapresiasikan realitas. Framing pada dasarnya merupakan pemberian definisi, penjelasan, evaluasi, dan rekomendasi dalam suatu wacana untuk menekankan kerangka berfikir tertentu terhadap peristiwa yang diwacanakan (Neviati, 2018).

Dalam penelitian analisis framing terdapat beberapa model, salah satunya adalah model Robert Entman. Analisis framing model Robert Entman dalam buku Analisis Framing (Eriyanto, 2002:165) menjelaskan bahwa framing bisa digunakan untuk meneliti praktik jurnalistik. Seperti jika ingin meneliti frame dapat mempengaruhi kerja wartawan, apa yang diperhatikan wartawan saat meliput peristiwa, aspek apa yang dilihat, bagaimana wartawan melihat sebuah peristiwa, serta bagaimana wartawan membuat satu informasi bisa lebih menonjol dari informasi yang lain.

Robert Entman melihat framing dalam dua dimensi besar, yang pertama yaitu sebagai seleksi isu, yang berhubungan dengan pemilihan fakta. Dari realitas yang kompleks dan beragam itu akan dipilih satu aspek yang diseleksi untuk ditampilkan. Dari proses ini selalu terkandung didalamnya ada bagian berita yang dimasukkan, tetapi ada juga yang dikeluarkan. Tidak semua aspek atau bagian berita ditampilkan (Eriyanto, 2002:186).

Entman mengatakan framing dilakukan dalam empat tahap, yaitu: 
Analisis Framing Pemberitaan Pilgub Jawa Timur 2018 pada Situs Berita Daring Indonesia pertama, pendefinisian masalah/define problem tentang bagaimana melihat suatu isu/peristiwa dan sebagai masalah apa isu/perisiwa itu dilihat, kedua, memperkirakan masalah atau sumber masalah/diagnose cause tentang peristiwa itu dilihat sebagai apa serta siapa yang dianggap sebagai penyebab dari suatu masalah. Ketiga membuat keputusan moral/make moral judgement tentang nilai moral apa yang disajikan untuk menjelaskan masalah dan nilai moral apa yang dipakai untuk menyatakan suatu tindakan, keempat, menekankan penyelesaian/treatment recommendation tentang penyelesaian apa yang ditawarkan untuk mengatasi masalah/isu dan jalan apa yang ditawarkan dan harus ditempuh untuk mengatasi masalah (Eriyanto, 2002: 189-190).

Tabel 1.2. Elemen Framing Model Robert Entman

$\begin{array}{cc}\begin{array}{c}\text { Define Problems } \\ \text { Pendefinisian Masalah) }\end{array} & \begin{array}{c}\text { Bagaimana suatu peristiwa atau isu dilihat? Sebagai apa? } \\ \text { Atau sebagai masalah apa? }\end{array} \\ \begin{array}{c}\text { Diagnose Cause } \\ \text { Memperkirakan Masalah atau } \\ \text { Sumber Masalah) }\end{array} & \begin{array}{c}\text { Peristiwa tersebut dilihat disebabkan oleh apa? Apa yang } \\ \text { dianggap sebagai penyebab dari suatu masalah? Siapa aktor } \\ \text { yang menyebabkan masalah? }\end{array} \\ \begin{array}{c}\text { Make Moral Judgement } \\ \text { Membuat Keputusan Moral) }\end{array} & \begin{array}{c}\text { Nilai moral yang disajikan untuk menjelaskan masalah? } \\ \text { Nilai moral apa yang dipakai untuk melegitimasi atau } \\ \text { mendelegitimasi suatu tindakan? }\end{array} \\ \begin{array}{c}\text { Treatment Recommendation } \\ \text { Menekankan Penyelesaian) }\end{array} & \text { Penyelesaian apa yang ditawarkan untuk mengatasi } \\ & \text { masalah? Jalan apa yang ditawarkan dan harus ditempuh } \\ \end{array}$

Sumber: Eriyanto, Analisis Framing, 2002

Penelitian ini merupakan penelitian kualitatif dalam upaya menganalisis serta mengetahui bagaimana media membingkai pemberitaan antar pasangan calon gubernur selama masa kampanye pemilihan Gubernur Jawa Timur tahun 2018 di JawaPos.com, Surya.co.id \& Tempo.co melalui analisis framing model Robert Entman. Peneliti menggunakan situs berita online, karena penetrasinya yang begitu luar biasa pada generasi milenial (Susilo, 2017). Untuk memperoleh berbagai data pendukung, peneliti menggunakan dua data yakni data primer dan data sekunder, dimana data primer pada penelitian ini meneliti teks berita dari media online sementara data sekunder berasal dari literatur atau studi kepustakaan dengan menggunakan literatur yang relevan dengan penelitian ini dan dapat menunjang dalam melakukan analisis yang terkait dengan objek penelitian.

\section{HASIL DAN PEMBAHASAN}

Sebagaimana yang telah terlihat dalam penjabaran di atas, maka penelitian ini akan berfokus pada pemberitaan JawaPos.com, Surya.co.id dan Tempo.co 
mengenai kampanye Pemilihan Cagub Jatim 2018 pada tanggal 11 April 2018 dimana total berita dari masing-masing media tersebut yaitu :

JawaPos.com $=14$ Berita

Surya.co.id = 15 Berita

Tempo.co = 4 Berita

Tempo.co sebagai media berita online menampilkan berbagai pemberitaan mengenai "Pemilihan Gubenur Jawa Timur 2018" dari berbagai hari, salah satu hari yang menjadi sorotan adalah pada tanggal 11 April 2018 dimana berita tersebut ditampilkan setelah Debat Publik 1 Pilgub Jatim. Tempo.co menampilkan sebanyak 4 berita pada tanggal 11 April 2018. Berdasarkan jumlah berita yang disampaikan oleh Tempo.co, penulis akan membahas 4 berita yang ditampilkan Tempo.co pada tanggal 11 April 2018 yang selanjutnya akan di analis dan di frame. Berita-berita tentang Pemilihan Gubenur Jawa Timur 2018 di Tempo.co antara lain :

Tabel 3.1 Berita terkait Pemilihan Gubenur di Tempo.co

\begin{tabular}{|c|c|}
\hline Tanggal & Judul \\
\hline Rabu, 11 April 2018 13:49 & $\begin{array}{l}\text { Saat Emil Dardak dan Puti Guntur Berdebat Sengit Soal } \\
\text { Gizi Buruk }\end{array}$ \\
\hline Rabu, 11 April 2018 13:11 & $\begin{array}{c}\text { Timses Pasangan Calon Pilgub Jatim } 2018 \text { Apresiassi } \\
\text { Debat Kandidat }\end{array}$ \\
\hline Rabu, 11 April 2018 11:29 & $\begin{array}{c}\text { Ketua KPU Menilai Debat Pilgub Jatim Berlangsung } \\
\text { Menarik }\end{array}$ \\
\hline Rabu, 11 April 2018 10:59 & $\begin{array}{c}\text { Khofifah Indar Parawansa Ingin Bangun Tempat } \\
\text { Perlindungan Anak }\end{array}$ \\
\hline
\end{tabular}

\section{Frame Tempo.co Terkait Pemilihan Gubenur Jawa Timur 2018}

Dari keseluruhan berita terkait "Pemilihan Gubenur Jawa Timur 2018" yang ditampilkan oleh Tempo.co penulis memilih berita Tempo.co tentang Pilkada Jawa Timur pada tanggal 11 April 2018 yang menjadi objek penelitian. Beritaberita tersebut adalah berita pada tanggal 11 April 2018 pukul 13:49 WIB yang berjudul "Saat Emil Dardak dan Puti Guntur Berdebat Sengit Soal Gizi Buruk", tanggal 11 April 2018 pukul 13:11 WIB yang berjudul "Timses Pasangan Calon Pilgub Jatim 2018 Apresiassi Debat Kandidat”, tanggal 11 April 2018 pukul 11:29 WIB yang berjudul "Ketua KPU Menilai Debat Pilgub Jatim Berlangsung Menarik", dan tanggal 11 April 2018 pukul 10:59 WIB yang berjudul "Khofifah Indar Parawansa Ingin Bangun Tempat Perlindungan Anak".

Jawapos.com sebagai media berita online menampilkan berbagai pemberitaan mengenai Pilkada salah satunya adalah Pemilihan Gubenur Jawa Timur 2018 dari berbagai hari, salah satu hari yang menjadi sorotan penulis dalam pemberitaan adalah pada tanggal 11 April 2018 dimana berita tersebut ditampilkan setelah Debat Publik 1 Pilgub Jatim. Jawapos.com menampilkan 
Analisis Framing Pemberitaan Pilgub Jawa Timur 2018 pada Situs Berita Daring Indonesia sebanyak 14 berita pada tanggal 11 April 2018. Berita-berita tentang Pemilihan Gubenur Jawa Timur 2018 di Jawapos.com antara lain :

Tabel 3.3 Berita terkait Pemilihan Gubenur di Jawapos.com

\begin{tabular}{|c|c|}
\hline Tanggal & Judul \\
\hline Rabu, 11 April 2018 22:57 & $\begin{array}{c}\text { Alumni Lirboyo Kompak Menangkan Gus Ipul-Mbak } \\
\text { Puti }\end{array}$ \\
\hline Rabu, 11 April 2018 18:57 & Khofifah Ajak Pengusaha Bangun Industri di Desa \\
\hline Rabu, 11 April 2018 16:26 & Pengamat: Data Khofifah-Emil Lebih Faktual \\
\hline Rabu, 11 April 2018 13:04 & $\begin{array}{c}\text { Loyalis Jokowi Semakin Semangat Menangkan } \\
\text { Khofifah-Emil }\end{array}$ \\
\hline Rabu, 11 April 2018 12:23 & Gus Ipul Antar Ra Lilur ke Peristirahatan Terakhir \\
\hline Rabu, 11 April 2018 11:16 & Pengamat: Gus Ipul dan Puti Lebih Cenderung Woles \\
\hline Rabu, 11 April 2018 10:38 & Khofifah-Emil Buktikan Layak Pimpin Jatim \\
\hline Rabu, 11 April 2018 08:55 & $\begin{array}{c}\text { Pengamat: Khofifah-Emil Unggul di Debat Perdana } \\
\text { Pilgub Jatim }\end{array}$ \\
\hline Rabu, 11 April 2018 08:13 & $\begin{array}{c}\text { Khofifah Perkuat Iktiar Lahir Batin, Gus Ipul Siap } \\
\text { Legowo }\end{array}$ \\
\hline Rabu, 11 April 2018 08:00 & Emil dan Gus Ipul Saling Sanggah Terkait Start Up \\
\hline Rabu, 11 April 2018 04:30 & $\begin{array}{c}\text { Sesi Tanya Jawab, Khofifah Pertanyakan Kerja Gus Ipul } \\
\text { Jadi Wagub }\end{array}$ \\
\hline Rabu, 11 April 2018 03:24 & $\begin{array}{c}\text { Soal TKI, Dua Paslon Sama-sama Prioritaskan } \\
\text { Penguatan Skill }\end{array}$ \\
\hline Rabu, 11 April 2018 01:47 & $\begin{array}{c}\text { Ini Komitmen Dua Paslon Pilgub Jatim Soal Pendidikan } \\
\text { Diniyah }\end{array}$ \\
\hline Rabu, 11 April 2018 23:35 & $\begin{array}{c}\text { Kunjungi Pusat Tahu Takwa Kediri, Ini Komitmen Gus } \\
\text { Ipul }\end{array}$ \\
\hline
\end{tabular}

\section{Frame Jawapos.com Terkait Pemilihan Gubenur}

Dari keseluruhan berita terkait "Pemilihan Gubenur Jawa Timur 2018" yang ditampilkan oleh Jawapos.com penulis memilih berita Jawapos.com tentang Pilkada Jawa Timur pada tanggal 11 April 2018 yang menjadi objek penelitian. Berita-berita tersebut adalah berita pada tanggal 11 April 2018 pukul 22:57 WIB yang berjudul "Alumni Lirboyo Kompak Menangkan Gus Ipul-Mbak Puti", tanggal 11 April 2018 pukul 18:57 WIB yang berjudul "Khofifah Ajak Pengusaha Bangun Industri di Desa", tanggal 11 April 2018 pukul 16:26 WIB yang berjudul "Pengamat: Data Khofifah-Emil Lebih Faktual", tanggal 11 April 2018 pukul 13:04 WIB yang berjudul "Loyalis Jokowi Semakin Semangat Menangkan Khofifah-Emil", tanggal 11 April 2018 pukul 12:23 WIB yang berjudul "Gus Ipul Antar Ra Lilur ke Peristirahatan Terakhir", tanggal 11 April 2018 pukul 11:16 WIB yang berjudul "Pengamat: Gus Ipul dan Puti Lebih Cenderung Woles", tanggal 11 April 2018 pukul 10:38 WIB yang berjudul "Khofifah-Emil Buktikan Layak Pimpin Jatim", tanggal 11 April 2018 pukul 08:55 WIB yang berjudul "Pengamat: Khofifah-Emil Unggul di Debat Perdana Pilgub Jatim", tanggal 11 April 2018 pukul 08:13 WIB yang berjudul "Khofifah Perkuat Iktiar Lahir Batin, Gus Ipul Siap Legowo", tanggal 11 April 2018 pukul 
08:00 WIB yang berjudul "Emil dan Gus Ipul Saling Sanggah Terkait Start Up", tanggal 11 April 2018 pukul 04:30 WIB yang berjudul "Sesi Tanya Jawab, Khofifah Pertanyakan Kerja Gus Ipul Jadi Wagub”, tanggal 11 April 2018 pukul 03:24 WIB yang berjudul "Soal TKI, Dua Paslon Sama-sama Prioritaskan Penguatan Skill", tanggal 11 April 2018 pukul 01:47 WIB yang berjudul "Ini Komitmen Dua Paslon Pilgub Jatim Soal Pendidikan Diniyah", dan tanggal 11 April 2018 pukul 23:35 WIB yang berjudul "Kunjungi Pusat Tahu Takwa Kediri, Ini Komitmen Gus Ipul”.

Surya.co.id menampilkan pemberitaan mengenai "Pemilihan Gubenur Jawa Timur 2018 sebanyak 15 berita yang disampaikan pada tanggal 11 April 2018. Berdasarkan jumlah berita yang disampaikan oleh Surya.co.id, Beritaberita tentang Pemilihan Gubenur Jawa Timur 2018 di Surya.co.id antara lain :

Tabel 3.5 Berita Pemilihan Gubenur Surya.co.id

\begin{tabular}{|c|c|}
\hline Tanggal & Judul \\
\hline Rabu, 11 April 2018 00:07 & $\begin{array}{c}\text { Tim Khofifah Sebut Debat Pertama Untungkan Paslon } \\
\text { Nomor Urut } 1\end{array}$ \\
\hline Rabu, 11 April 2018 00:18 & $\begin{array}{l}\text { Pengamat Unair: Khofifah-Emil Bicara Data, Gus-Ipul } \\
\text { Inginkan Program Perubahan Keberlanjutan }\end{array}$ \\
\hline Rabu, 11 April 2018 00:26 & $\begin{array}{c}\text { Pengamat Universitas Brawijaya: Khofifah-Emil Unggul di } \\
\text { Debat Kandidat Perdana Pilgub Jatim }\end{array}$ \\
\hline Rabu, 11 April 2018 00:32 & $\begin{array}{c}\text { Terlibat Debat Panas Dengan Emil, Begini Tanggapan } \\
\text { Puti Soekarno }\end{array}$ \\
\hline Rabu, 11 April 2018 00:43 & $\begin{array}{l}\text { Ketua KPU RI Hadiri Debat Pilgub Jatim, Arief Budiman: } \\
\text { Sangat Menarik, Tinggal Pemilih Mencermati }\end{array}$ \\
\hline Rabu, 11 April 2018 01:02 & $\begin{array}{c}\text { Terlibat Debat Sengit Dengan Mbak Puti, Begini Reaksi } \\
\text { Emil Dardak }\end{array}$ \\
\hline Rabu, 11 April 2018 07:18 & $\begin{array}{l}\text { Manfaatkan Bonus Demografi, Khofifah-Email } \\
\text { Canangkan Program Millenial Job Center }\end{array}$ \\
\hline Rabu, 11 April 2018 12:19 & $\begin{array}{l}\text { Bara JP Makin Berenergi Kampanyekan Pasangan } \\
\text { Khofifah Indar Parawansa-Emil Dardak }\end{array}$ \\
\hline Rabu, 11 April 2018 19:05 & $\begin{array}{l}\text { Forum Pengusaha Jatim Mengaku Cocok Dengan } \\
\text { Program Khofifah, Siap Relokasi Industri di Pedesan }\end{array}$ \\
\hline Rabu, 11 April 2018 21:08 & $\begin{array}{c}\text { Entaskan Kemiskinan, Perlu Relokasi Industri Dari Kota } \\
\text { ke Desa }\end{array}$ \\
\hline Rabu, 11 April 2018 21:12 & $\begin{array}{l}\text { Apresiasi Debat, Relawan Jokowi Sebut Gus Ipul-Puti } \\
\text { Implementasikan Bela Kaum Marjinal }\end{array}$ \\
\hline Rabu, 11 April 2018 21:16 & Gus Ipul Hadiri Pertemuan Alumni Santri Lirboyo \\
\hline Rabu, 11 April 2018 21:28 & $\begin{array}{l}\text { Gus Ipul Komitmen Ciptakan Swasembada Kedelai di } \\
\text { Jatim }\end{array}$ \\
\hline Rabu, 11 April 2018 22:43 & $\begin{array}{c}\text { Kuasai Kursi di DPRD Gresik, Parpol Pengusung } \\
\text { Khofifah - Emil Yakin Raih Suara } 65 \text { Persen }\end{array}$ \\
\hline Rabu, 11 April 2018 22:46 & Alumni Ponpes Lirboyo Deklarasi Dukung Gus Ipul \\
\hline
\end{tabular}




\section{Frame Surya.co.id Terkait Pemilihan Gubenur}

Analisis Framing Pemberitaan Pilgub Jawa Timur 2018 pada Situs Berita Daring Indonesia

Dari keseluruhan berita terkait "Pemilihan Gubenur Jawa Timur 2018" penulis memilih 15 berita yang menjadi objek penelitian. Berita-berita tersebut adalah berita pada tanggal 11 April 2018 pukul 00:07 yang berjudul "Tim Khofifah Sebut Debat Pertama Untungkan Paslon Nomor Urut 1", tanggal 11 April 2018 pukul 00:18 yang berjudul "Pengamat Unair: Khofifah-Emil Bicara Data, GusIpul Inginkan Program Perubahan Keberlanjutan", tanggal 11 April 2018 pukul 00:26 yang berjudul "Pengamat Universitas Brawijaya: Khofifah-Emil Unggul di Debat Kandidat Perdana Pilgub Jatim” tanggal 11 April 2018 pukul 00:32 yang berjudul "Terlibat Debat Panas Dengan Emil, Begini Tanggapan Puti Soekarno", tanggal 11 April 2018 pukul 00:43 yang berjudul "Ketua KPU RI Hadiri Debat Pilgub Jatim, Arief Budiman: Sangat Menarik, Tinggal Pemilih Mencermati", tanggal 11 April 2018 pukul 01:02 yang berjudul "Terlibat Debat Sengit Dengan Mbak Puti, Begini Reaksi Emil Dardak", tanggal 11 April 2018 pukul 07:18 yang berjudul "Manfaatkan Bonus Demografi, Khofifah-Email Canangkan Program Millenial Job Center", tanggal 11April 2018 pukul 12:19 yang berjudul "Bara JP Makin Berenergi Kampanyekan Pasangan Khofifah Indar Parawansa-Emil Dardak", tanggal 11April 2018 pukul 19:05 yang berjudul "Forum Pengusaha Jatim Mengaku Cocok Dengan Program Khofifah, Siap Relokasi Industri di Pedesan", tanggal 11April 2018 pukul 21:08 yang berjudul "Entaskan Kemiskinan, Perlu Relokasi Industri Dari Kota ke Desa", tanggal 11April 2018 pukul 21:12 yang berjudul "Apresiasi Debat, Relawan Jokowi Sebut Gus Ipul-Puti Implementasikan Bela Kaum Marjinal”, tanggal 11 April 2018 pukul 21:16 yang berjudul "Gus Ipul Hadiri Pertemuan Alumni Santri Lirboyo", tanggal 11 April 2018 pukul 21:28 yang berjudul "Gus Ipul Komitmen Ciptakan Swasembada Kedelai di Jatim", tanggal 11 April 2018 pukul 22:43yang berjudul "Kuasai Kursi di DPRD Gresik, Parpol Pengusung Khofifah - Emil Yakin Raih Suara 65 Persen" dan tanggal 11 April 2018 pukul 22:46 yang berjudul "Alumni Ponpes Lirboyo Deklarasi Dukung Gus Ipul”.

Dari temuan berita di atas, peneliti menganalisis 2 (dua) berita dari masing-masing media online secara acak :

Analisis Framing Robert N. Entman Pemberitaan Tempo.co

Judul 1 : "Saat Emil Dardak dan Puti Guntur Berdebat Sengit Soal Gizi Buruk"

\begin{tabular}{cc}
\hline Define Problems & Tempo.co mengidentifikasi bahwa debat antara Emil Dardak \\
(Pendefinisian Masalah) & Tan Puti Guntur berdebat sengit soal gizi buruk. Frame \\
& Tempo.co dalam penyampaian berita ini adalah mengenai \\
& $\begin{array}{c}\text { suasana sengit antara kedua calon wakil gubenur khususnya saat } \\
\text { terjadi perdebatan tentang tema kesejahteraan rakyat khususnya } \\
\text { mengenai gizi buruk }\end{array}$ \\
$\begin{array}{c}\text { Diagnose Cause } \\
\text { (Memperkirakan Masalah } \\
\text { atau Sumber Masalah) }\end{array}$ & $\begin{array}{c}\text { Dalam berita ini Tempo.co lebih menonjolkan bahwa suasana } \\
\text { debat terasa sengit antara calon wakil gubenur Jawa Timur (Puti }\end{array}$ \\
\hline
\end{tabular}


Make Moral Judgement (Membuat Keputusan Moral)

Treatment

Recommendation

(Menekankan

Penyelesaian) menyoroti angka kecukupan gizi di Kabupaten Trenggalek yang dipimpin Emil Dardak, akan tetapi Emil membalasnya dengan pertanyaan balik mengenai definisi berbagai jenis masalah kesehatan anak.

Frame akan adanya "Pemilihan Gubenur Jawa Timur 2018" sebagai dasar dari terjadinya beritaan serta hal-hal lain yang berhubungan dengan citra unggul dari masing-masing pasangan. Maka penilian moral yang dikenakan dalam berita ini adalah suasana debat pilgub 1 terasa sengit karena calon wakil gubenur nomor urut 2 Puti Guntur yang mencoba memancing suasana sengit dengan mengajukan pertanyaan mengenai gizi buruk yang terjadi di Kabupaten Trenggalek dimana Emil Dardak selaku pemimpinnya. Namun Emil membalas pertanyaan tersebut dengan balik mendefinisikan berbagai jenis masalah kesehatan yang terjadi di Jawa Timur dan Trenggalek khususnya.

Dalam berita ini, Tempo.co melihat bahwa suasana sengit terjadi karena Puti Guntur mengajukan pertanyaan tentang gizi buruk di Kabupaten Trenggalek dan Emil selaku penerima pertanyaan mampu menjawab dengan baik ditambah dengan sorakan masing-masing pendukung dari calon kandidat yang membuat suasana riuh. Selain itu, Tempo.co juga memberikan informasi dalam berita ini bahwa perdebatan dalam mempertahankan argumentasi merupakan hal biasa dalam proses demokrasi.

\section{Judul 2 : "Timses Pasangan Calon Pilgub Jatim 2018 Apresiassi Debat Kandidat"}

Define Problems

(Pendefinisian Masalah)

Diagnose Cause

(Memperkirakan Masalah atau Sumber Masalah)

Make Moral Judgement

(Membuat Keputusan Moral)
Tempo.co mengidentifikasi bahwa hasil dari debat pilgub 1 Jatim telah membuat timses pasangan calon pilgub jatim 2018 apresiassi debat kandidat. Frame Tempo.co dalam penyampaian berita ini adalah mengenai jalannya debat, dimana selama debat berlangsung para kandidat calon gubenur dan wakil gubenur mampu menyampaikan harapan dan terangkum dalam visi dan misi dengan baik yang sesuai dengan harapan masyarakat

Dalam berita ini Tempo.com lebih menonjolkan bahwa debat pilgub 1 Jawa Timur 2018 memberikan kesan atau informasi bahwa masing-masing kandidat memiliki visi dan misi baik, yang terangkum dalam program berkualitas masing-masing kandidat. Proses debat pilgub 1 Jawa Timur 2018 telah memiliki penilian sendiri dari masyarakat, dan tim sukses tinggal melakukan hanya diperlukan perbaikan untuk bantuan data apabila tiap pasangan calon membutuhkan.

Frame akan adanya "Pemilihan Gubenur Jawa Timur 2018" sebagai dasar dari terjadinya beritaan serta hal-hal lain yang berhubungan dengan citra unggul dari masing-masing pasangan. Maka penilaian moral yang dikenakan dalam berita ini adalah debat antara masing-masing kandidat mampu 
Analisis Framing Pemberitaan Pilgub Jawa Timur 2018 pada Situs Berita Daring Indonesia memberikan informasi mengenai visi dan misi yang terangkum dalam program masing-masing kandidat berkualitas. Selain itu, masing-masing kandidat mampu mewujudkan harapan masingmasing tim sukses dengan memberikan tampilan terbaik dalam debat pertama pada tanggal 10 April 2018.

Treatment

Recommendation

(Menekankan

Penyelesaian)

harapan masing-masing tim sukses. Dimana penyampaian program-program dan suasana debat berlangsung dengan baik.

Tinggal pengembangan data-data saja guna menyokong kenyataan yang terjadi

\section{Analisis Framing Robert N. Entman Pemberitaan JawaPos.com Judul 1 : "Alumni Lirboyo Kompak Menangkan Gus Ipul-Mbak Puti"}

\begin{tabular}{|c|c|}
\hline $\begin{array}{c}\text { Define Problems } \\
\text { (Pendefinisian Masalah) }\end{array}$ & $\begin{array}{l}\text { JawaPos.com mengidentifikasi bahwa Silahturahmi Gus Ipul } \\
\text { pada Himpunan Alumni Santri Lirboyo (Himasal) membuat } \\
\text { Gus Ipul memperoleh dukungan penuh terahadap hak pilih } \\
\text { pada Pemilihan Gubernur pada } 27 \text { Juni 2018. Frame } \\
\text { JawaPos.com dalam penyampaian berita ini adalah mengenai } \\
\text { alumni Lirboyo kompak menangkan Gus Ipul-Mbak Puti. }\end{array}$ \\
\hline $\begin{array}{c}\text { Diagnose Cause } \\
\text { (Memperkirakan Masalah } \\
\text { atau Sumber Masalah) }\end{array}$ & $\begin{array}{c}\text { Dalam berita ini JawaPos.com lebih menonjolkan kepatuhan } \\
\text { para santri dalam mematuhi perintah kiayi dimana menurut } \\
\text { kiayi Gus Ipul merupakan sosok yang baik untuk memimpin } \\
\text { Jawa Timur dan telah mengagap Gus Ipul sebagai bagian dari } \\
\text { keluarga besar Lirboyo }\end{array}$ \\
\hline $\begin{array}{c}\text { Make Moral Judgement } \\
\text { (Membuat Keputusan } \\
\text { Moral) }\end{array}$ & $\begin{array}{l}\text { Frame akan adanya "Pemilihan Gubenur Jawa Timur } 2018 \text { " } \\
\text { sebagai dasar dari terjadinya beritaan serta hal-hal lain yang } \\
\text { berhubungan dengan citra unggul dari masing-masing } \\
\text { pasangan. Maka penilian moral yang dikenakan dalam berita ini } \\
\text { adalah adanya dukungan penuh dari alumni Lirboyo terhadap } \\
\text { Gus Ipul sehingga mempengaruhi seluruh santri yang berada di } \\
\text { Jawa Timur untuk mendukung Gus Ipul-Mbak Puti. }\end{array}$ \\
\hline $\begin{array}{l}\text { Treatment } \\
\text { Recommendation } \\
\text { (Menekankan } \\
\text { Penyelesaian) }\end{array}$ & $\begin{array}{l}\text { Dalam berita ini, JawaPos.com melihat bahwa Gus Ipul } \\
\text { merupakan sosok yang baik untuk memimpin Jawa Timur dan } \\
\text { merupakan bagian dari keluarga besar Lirboyo. }\end{array}$ \\
\hline
\end{tabular}

Judul (10) : "Emil dan Gus Ipul Saling Sanggah Terkait Start Up"

\begin{tabular}{cc}
\hline $\begin{array}{c}\text { Define Problems } \\
\text { (Pendefinisian Masalah) }\end{array}$ & $\begin{array}{c}\text { JawaPos.com mengidentifikasi bahwa terjadi saling sanggah } \\
\text { terhadap masing-masing kandidat. Frame JawaPos.com dalam } \\
\text { penyampaian berita ini adalah sikap saling sanggah diawali } \\
\text { antara Gus Ipul dan Emil. }\end{array}$ \\
$\begin{array}{c}\text { Diagnose Cause } \\
\text { (Memperkirakan Masalah } \\
\text { atau Sumber Masalah) }\end{array}$ & $\begin{array}{c}\text { Dalam berita ini JawaPos.com lebih menonjolkan sikap saling } \\
\text { sanggah yang dilakukan oleh masing-masing kandidat baik } \\
\text { wakil maupun gubenur, karena masing-masing kandidat } \\
\text { memiliki opininya sendiri. }\end{array}$ \\
\hline
\end{tabular}

Communicatus: Jurnal Ilmu Komunikasi 3(1) (2018) 91-110 
Nur Hamidah Zulaikha

\begin{tabular}{cc}
\hline $\begin{array}{c}\text { Make Moral Judgement } \\
\text { Membuat Keputusan } \\
\text { Moral) }\end{array}$ & $\begin{array}{c}\text { Frame akan adanya "Pemilihan Gubenur Jawa Timur 2018" } \\
\text { sebagai dasar dari terjadinya beritaan serta hal-hal lain yang } \\
\text { berhubungan dengan citra unggul dari masing-masing } \\
\text { pasangan. Maka penilian moral yang dikenakan dalam berita ini } \\
\text { adalah pemikiran Emil dengan Gus Ipul dalam melihat dunia } \\
\text { start up. }\end{array}$ \\
$\begin{array}{c}\text { Treatment } \\
\text { Dalam berita ini, Jawa Pos.com melihat bahwa masing-masing } \\
\text { kemmendation } \\
\text { Penekankan }\end{array}$ & di kasus Jawa timur. \\
\hline
\end{tabular}

Analisis Framing Robert N. Entman Pemberitaan Surya.co.id

Judul (2) "Pengamat Unair: Khofifah-Emil Bicara Data, Gus-Ipul Inginkan Program Perubahan Keberlanjutan"

$\begin{array}{cc}\text { Define Problems } & \text { Surya.co.id mengidentifikasi bahwa debat pertama antara } \\ \text { (Pendefinisian Masalah) } & \text { pasangan no urut } 1 \text { dan no ururt } 2 \text { di Pemilihan Gubenur Jawa } \\ & \text { Timur 2018 menjelaskan bahwa program yang dibawanya } \\ & \text { program yang berkelanjutan. Hal tersebut terlihat saat Gus Ipul } \\ & \text { menjelaskan bahwa pembangunan berkelanjutan sesuai } \\ & \text { platform. Gus Ipul juga ingin menunjukkan pola komunikasi } \\ & \text { yanng dekat dengan masyarakat. Masing-masing memiliki } \\ & \text { kelebihan. Selain Cagub, Cawagub juga menunjukkan posisi } \\ & \text { masing-masing calon. Terlihat dari Emil yang sangat agresif } \\ & \text { saat menjawab soal kondisi anak gagal tumbuh atau stunting di } \\ & \text { Kabupaten Trenggalek, di mana Emil menjadi Bupati. } \\ & \text { Dalam berita ini Surya.co.id lebih menonjolkan bahwa kedua } \\ \text { pasang saling menunjukkan posisi masing-masing pada Debat } & \text { Pertama tanggal 10 April 2018 dan seharusnya masyarakat } \\ \text { Diagnose Cause } & \text { mampu mencermatinya dengan baik. } \\ \text { atau Sumber Masalah) } & \text { Frame akan adanya "Pemilihan Gubenur Jawa Timur 2018" } \\ \text { Make Moral Judgement } & \text { sebagai dasar dari terjadinya beritaan serta hal-hal lain yang } \\ \text { (Membuat Keputusan } & \text { berhubungan dengan citra unggul dari masing-masing } \\ \text { Moral) } & \text { pasangan. Hal tersebut sesuai dengan yang diungkapkan } \\ & \text { pengamat politik Universitas Airlangga, Novri Susan, } \\ & \text { mengatakan, dari penampilan di debat terlihat jelas bagaimana } \\ & \text { posisi yang diambil dari masing-masing calon. Dan tinggal } \\ & \text { pemilih yang akan mencermati masing-masing kandidat. } \\ & \text { Meskipun pada debat pertama "Pemilihan Gubener Jawa } \\ & \text { Timur 2018" sedikit memakan emosi kedua paslon. Tetapi hal } \\ & \text { tersebut mampu memberikan penilaian tersendiri kepada } \\ \text { masing-masing kandidat untuk memperoleh nilai dari } & \text { masyarakat. Dan masyarakat dapat lebih cermat mana paslon } \\ \text { Treatment } & \text { yang memiliki kandidat terbaik. Sebab masing-masing calon } \\ \text { (Menekankan } & \text { telah menunjukkan posisi masing-masing dalam debat. } \\ \text { Penyelesaian) } & \end{array}$

Judul (7) : "Manfaatkan Bonus Demografi, Khofifah-Email Canangkan Program 
Define Problems

(Pendefinisian Masalah)

Diagnose Cause (Memperkirakan Masalah atau Sumber Masalah)

Make Moral Judgement

(Membuat Keputusan Moral)

Treatment

Recommendation

(Menekankan

Penyelesaian)
Surya.co.id mengidentifikasi bahwa dengan ada bonus demografi, Khofifah-Emil manfaatkan Program Millienial Job

Center. Frame Surya.co.id dalam penyampaian berita ini adalah manfaatkan Program Millienial Job Center. Menjawab permasalahan tersebut cawagub Jawa Timur nomor urut 1 Emil

Elestianto Dardak bicara tentang bonus demografi maka menyangkut generasi muda.

Dalam berita ini Surya.co.id lebih menonjolkan jawaban apa yang ditawarkan pasangan Khofifah Emil memiliki program yang realistis dan sesuai dalam mengatasi permasalahan yang ada.

Frame akan adanya "Pemilihan Gubenur Jawa Timur 2018" sebagai dasar dari terjadinya beritaan serta hal-hal lain yang berhubungan dengan citra unggul dari masing-masing pasangan.

Maka penilian moral yang dikenakan dalam berita ini adalah

Khofifah-Emil mencoba mengatasi permasalahan yang ada dengan Job Center Millineal.

Dalam berita ini, Surya.co.id melihat bahwa Khofifah berfokus pada program yang sesuai dengan yang dibawakan oleh permasalahan yang ada.

Uraian analisis yang telah disampaikan menunjukkan bahwa setiap portal berita memberikan sudut pandang yang hampir sama terhadap Pemilihan Gubenur Jawa Timur 2018. Adanya sudut pandang yang hampir sama atau tidak jauh berbeda tersebut selanjutnya juga memberikan pandangan yang sedikit berbeda terhadap berita yang tersampaikan, keputusan moral dan penyelesiaan masalah yang berbeda pula. Setelah dilakukan analisis secara mendalam, ternyata hal tersebut dipengaruhi dengan adanya gatekeeper.

Media massa tidak berdiri sendiri, di dalamnya ada beberapa individu yang bertugas melakukan pengolahan informasi sebelum informasi itu sampai kepada khalayak. Mereka yang bertugas itu sering disebut dengan gatekeeper. Jadi, informasi yang diterima audien dalam komunikasi massa sebenarnya sudah diolah oleh gatekeeper dan disesuaikan dengan misi, visi, media yang bersangkutan, khalayak sasaran dan orientasi bisnis atau idel yang menyertainya.

Adanya gatekeeper yang menyesuaikan berita dengan hal-hal terkait perusahaan terlihat pada peristiwa pemberitaan tentang Pemilihan Gubenur Jawa Timur 2018. oleh JawaPos.com dengan objektif, memberikan wawasan dan pengetahuan. Sementara, untuk pemberitaan yang ditulis oleh Surya.co.id sebagai portal berita nasional terkini juga memberikan informasi detail mengenai kegiatan masing-masing kandidat pada Pemilihan Gubenur Jawa Timur 2018.

Berbeda dengan berita yang ditulis oleh Tempo.com. Pada portal berita ini, Pemilihan Gubenur Jawa Timur 2018 yang berfokus pada pemberitaan ini 
mengenai hasil debat pada tanggal 10 April 2018 tanpa memberi embel-embel tentang kegiatan masing-masing kandidat Gubenur Jawa Timur 2018. Berdasarkan uraian di atas maka dapat disimpulkan bahwa gatekeeper dengan mempertimbangkan kepentingan misi dan visi perusahaan berpengaruh pada sudut pandang penulisan berita.

\section{PENUTUP}

Setiap media massa memiliki perbedaan dalam membingkai sebuah berita. Frame ini tergantung pada kepentingan suatu media sehingga memperlihatkan konstruksi media atas suatu realitas. Dalam suatu peristiwa yang sama, bisa dipandang berbeda oleh setiap media karena terkait dengan proses pembuatan berita yang telah dikonstruksi realitas. Berita ini lalu dibentuk dengan frame melalui selesi penekanan terhadap sebuah isu.

Oleh karena itu, penulis mengambil kesimpulan bahwa Tempo.co, Surya.co.id dan JawaPos.com memiliki perbedaan dalam membingkai isu pemberitan Pemilihan Gubenur Jawa Timur 2018, sebagai berikut:

Pertama, Pengemasan berita yang dilakukan oleh Tempo.co terkait Pemilihan Gubenur Jawa Timur Tahun 2018 lebih menekankan pada berita pasangan Khofifah-Emil mengenai suasana debat serta visi-misi kesejateraan rakyat. Terlihat dari berita yang disajikan, dimana Tempo.com hanya menyajikan empat berita yang terdiri dari dua beritas tentang suasana debat pilgub yang menarik antara kedua pasalon, satu berita yang berisi mengenai susasan cawagub berdebat dan satu berita yang menjelaskan tentang keinginan atau visi-misi Khofifah untuk membangun Jawa Timur jika terpilih nanti salah satunya membangun tempat perlindungan anak.

Kedua, Media online JawaPos.com mengemas berita terkait Pemilihan Gubenur Jawa Timur Tahun 2018 lebih menekankan pada visi - misi masingmasing paslon serta citra positif masing-masing paslon yang diimbangi oleh beberapa penekanan berita terhadap paslon. Hal ini terlihat pada berita yang disajikan, dimana JawaPos.com saat memberitakan citra positif Khofiah - Emil, tidak lupa juga memberitakan citra positif Gus Ipul - Mbak Puti. JawaPos.com juga menyajikan berita yang sedikit menggiring opini masyarakat kepada masingmasing paslon untuk unggul memimpin Jatim.

Ketiga, Media online Surya.co.id mengemas berita terkait Pemilihan Gubenur Jawa Timur Tahun 2018 lebih seimbang dalam memberi porsi pemberitaan terhadap masing-masing paslon. Hal ini terlihat pada berita yang disajikan, dimana Surya.co.id memberitakan citra, visi-misi dan hasil debat masing-masing paslon secara seimbang, ketika berita yang disajikan Khofiah Emil, maka akan hadir berita Gus Ipul - Mbak Puti, atau dalam satu berita mencakup kedua paslon dalam satu topik. 


\section{DAFTAR PUSTAKA}

Analisis Framing Pemberitaan Pilgub Jawa Timur 2018 pada Situs Berita Daring Indonesia

Basyah, M. N. (2010). Pemantapan Wawasan Kebangsaan dalam Mengsukseskan Pilkada 2011. Jurnal Mentari, 13(1).

Eriyanto. (2002). Analisis Framing Konstruksi, Ideologi, dan Politik Media. Yogyakarta: LKiS.

Hamid, A. (2011). Politisasi Birokrasi dalam Pilkada Banten 2006. JLAN A: Jurnal Ilmu Administrasi Negara, 11(2).

Hendrik, D. (2010). Variabel-variabel yang Mempengaruhi Rendahnnya Partisipasi Politik Masyarakat dalam Pilkada Walikota dan Wakil Walikota

Padang Tahun 2008. Demokrasi: Jurnal Ilmiah Politik Kenegaraan, 9(2).

Humaedi, dkk. (2018). Resolusi Konflik Pilkada di Kota Cimahi Jawa Barat. Social Work, 8(1).

Hutagalung, I. (2013). Sistem Pers Tanggung Jawab Sosial. Jurnal Interaksi. 2(2). No 2.

Insani, M. A. (2013). Strategi Kemenangan Pasangan Tatto Suwarto PamujiAkhmad Edy Susanto dalam Pilkada Kabupaten Cilacap Tahun 2012. Journal of Politic And Government Studies, 2(1).

Launtu, A. (2009). Analisis dan Eksistensi Politik Kandidat Walikota dalam Meyakinkan Pemilih Pada Pilkada Kota Makassar di Tinjau dari Aspek Marketing Mix. Akmen Jurnal Ilmiah, 6(2).

Masduki. (2007). Regulasi Penyiaran dari Otoriter ke Liberal. Yogyakarta: LkiS Yogyakarta.

Masitoh dkk. (2013) Fenomena Golput Pada Pilkada Pati 2011. Journal of Politic and Government Studies, 2(3).

Maula, G. A. dkk. (2013). Kemenangan Kembali Mantan Bupati Amat Antono Pada Pilkada Kabupaten Pekalongan Tahun 2011. Journal of Politic and Government Studies, 2(3).

Muchtar, K. (2016). Komunikasi Politik dan Pembentukan Citra Partai. Jurnal Ilmu Komunikasi, 14(2), 136-147.

Muis, A. (2009). Peran dan Fungsi DPRD dalam Pelaksanaan Pilkada Menurut Undang-Undang No. 32 Tahun 2004. Jurnal FISIP, 10(2).

Neviati, C. Z. (2018). Study Case : A Tyleno Tale Makes Dies Who Consums With Framing Method. Jurnal Ilmu Komunikasi, 2(2).

Siregar, S. B. (2012). Implementasi Penerapan Pilkada pada daerah Pemekaran. Jurnal Konstitusi, 1(1).

Susila, A. (2009). Pilkada Kabupaten Bekasi 2007: Mengakhiri Sebuah Krisis Politik. Jurnal FISIP. 9(1).

Susilo, D., \& Haezer, E. (2017). Konstruksi Seksualitas Perempuan dalam Berita Pemerkosaan di Teks Media Daring.. Jurnal Kawistara, 7(1), 41-55. 
Nur Hamidah Zulaikha

Wisnumurti, O dkk. (2011). Local Political Dynamics In The General Election Directly Conducted To Vote For District Heads (Pilkada) In Badung Regency In 2005. E-Journal Of Cultural Studies, 5(2). 